\title{
Social Implications of Unburied Corpses from Intergroup Conflicts: Postmortem Agency Following the Sandby borg Massacre
}

\author{
Clara Alfsdotter
}

A massacre took place inside the Sandby borg ringfort, southeast Sweden, at the end of the fifth century. The victims were not buried, but left where they died. In order to understand why the corpses were left unburied, and how they were perceived following the violent event, a theoretical framework is developed and integrated with the results of osteological analysis. I discuss the contemporary normative treatment of the dead, social response to death and postmortem agency with emphasis on intergroup conflict and 'bad death'. The treatment of the dead in Sandby borg deviates from known contemporary practices. I am proposing that leaving the bodies unburied might be viewed as an aggressive social action. The corpses exerted postmortem agency to the benefit of the perpetrators, at the expense of the victims and their sympathizers. The gain for the perpetrators was likely political power through redrawing the victim's biographies, spatial memory and the social and territorial landscape. The denial of a proper death likely led to shame, hindering of regeneration and an eternal state of limbo.

\section{Introduction}

Although research on mass violence and on corporeality is extensive within the social sciences and humanities (see Knüsel \& Smith 2014; Martin et al. 2012, for bioarchaeological developments in violence research), the complexity of dead bodies in the context of mass violence is largely unexplored, despite the fact that the treatment of corpses strongly impacts society and helps understand the process of mass violence (Anstett \& Dreyfus 2014). In this article, I aim to connect strands of theory concerning mortuary rituals with those of violent death in order to create a theoretical framework that enables an exploration of the possible social implications of corpses from past mass violence. Specifically, this is done by combining the theoretical framework developed here with osteological empirical analysis and contextual analyses from the Iron Age ringfort Sandby borg, where the dwellers were killed and left unburied. In previous articles, the biological materiality of the dead in Sandby borg was investigated. This led to the conclusion that the corpses were not manipulated following the massacre, but seemingly left where they died (Alfsdotter et al. 2018; Alfsdotter \& Kjellström 2018; in preparation). In this article, I investigate the social response to the deaths in order to understand the contemporary implications of the Sandby borg corpses.

I present the context of Sandby borg and customary regional Iron Age mortuary practice. Thereafter, I discuss social responses to death and introduce the concept of postmortem agency in general, and in relation to lethal inter-group conflict in particular. Throughout the exposition I discuss the theories in relation to the human remains encountered inside the Iron Age Sandby borg ringfort.

\section{The Sandby borg ringfort}

The ringfort 'Sandby borg' is located on the Baltic island of Öland, present-day Sweden (Fig. 1). During 


\section{Clara Alfsdotter}

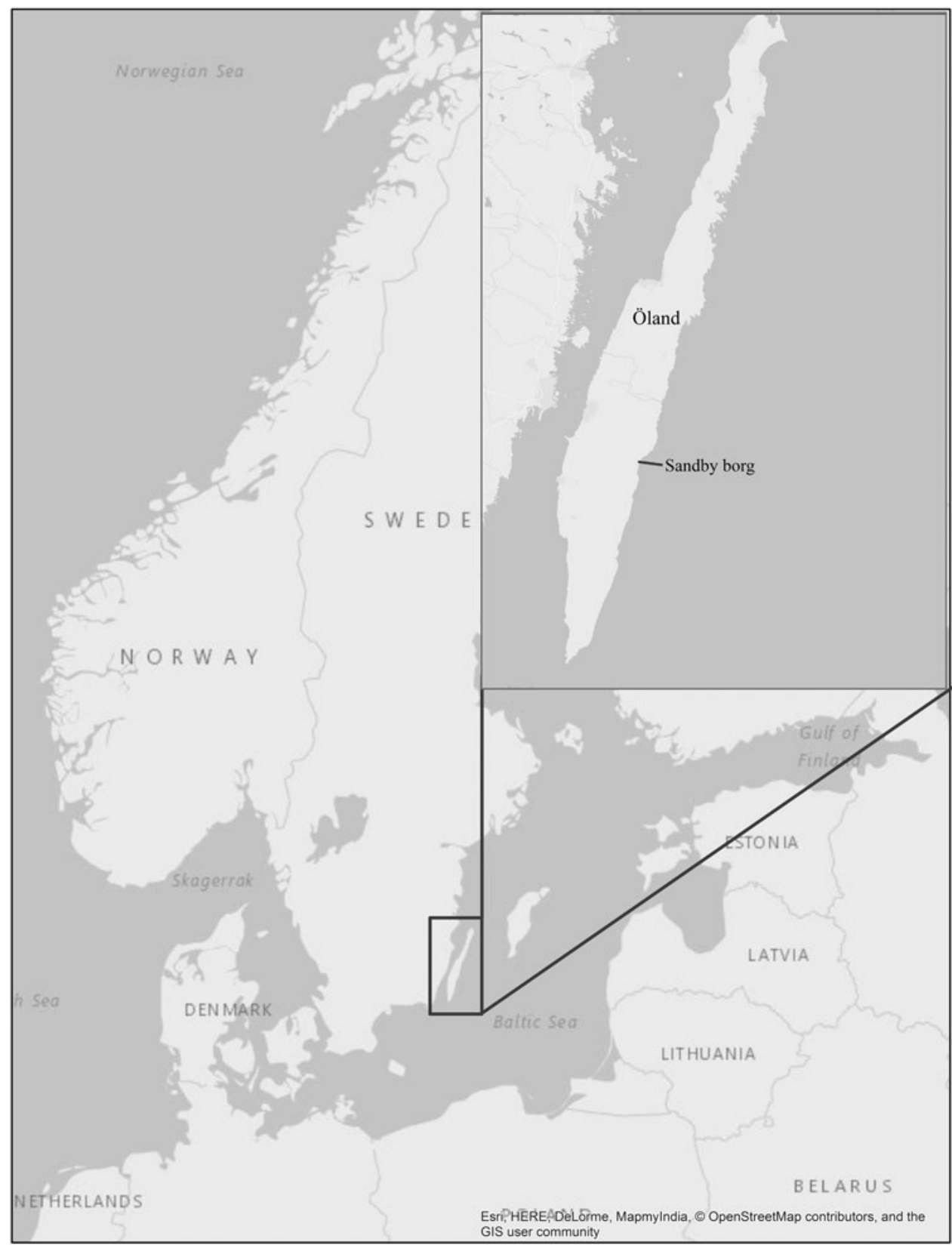

Figure 1. Scandinavia, with Öland and Sandby borg indicated. (Basemap (C) OpenStreetMap contributors, modified by Helena Victor.)

the early and middle Iron Age (Table 1), several ringforts were erected on the island; the remains of 16 are still visible today (Wegraeus 1976). Several Öland ringforts, Sandby borg included, were seemingly used as fortified villages, with houses enclosed by a high circular limestone wall (Fig. 2; Skarin-Frykman 1967; Stenberger 1933; Wegraeus 1976). There is no consensus regarding whether the ringforts were
Table 1. Schematic chronology of the Swedish Iron Age Periods.

\begin{tabular}{|l|l|}
\hline Date & \multicolumn{1}{|c|}{ Period } \\
\hline $500-1$ вс & Pre-Roman Iron Age \\
\hline AD 1-400 & Roman Iron Age \\
\hline AD 400-550 & Migration Period \\
\hline AD 550-750 & Vendel Period \\
\hline AD $750-1050$ & Viking Age \\
\hline
\end{tabular}


(a)

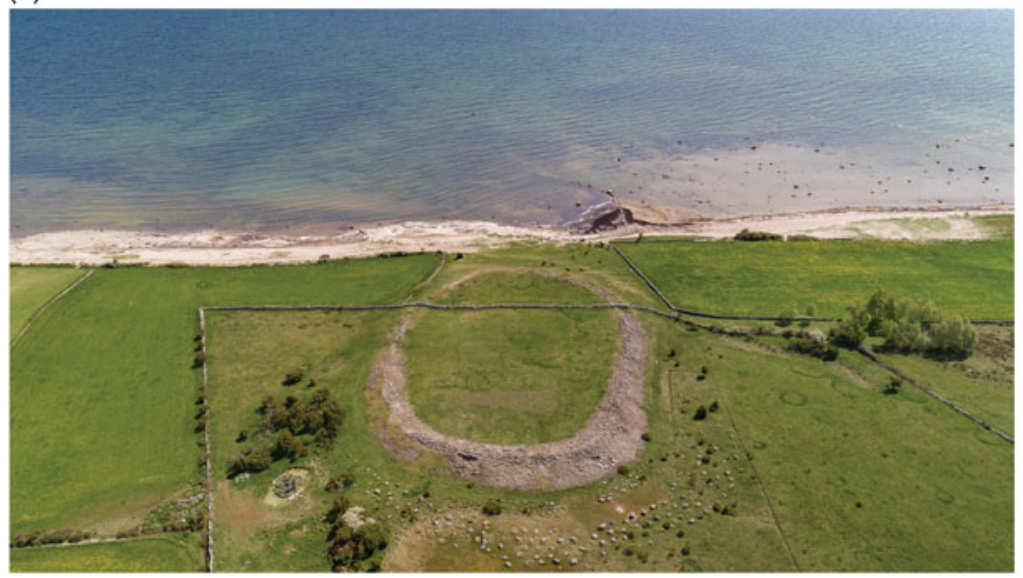

(b)

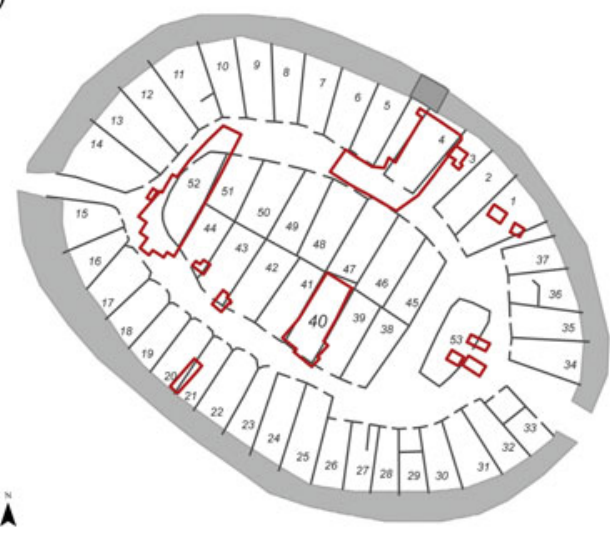

(c)

Figure 2. (a) The remains of Sandby borg as visible today. (Photograph: Sebastian Jakobsson); (b) Plan of Sandby borg based on excavations, aerial photographs and geophysical surveys (Viberg 2012). Three complete houses, minor parts of another six houses and sections of the street surrounding the central block have been excavated between 2011 and 2017 (Dutra Leivas \& Victor 2011; Gunnarsson et al. 2016; Papmehl-Dufay $\mathcal{E}$ Alfsdotter 2016; Victor 2012; 2014; Victor et al. 2013). Excavated areas are indicated (Figure: Helena Victor); (c) During excavations in 2016 house 4 and part of the adjacent street were investigated. The gables of houses 5 and 6 are visible in the left of the picture. Houses 4 and 5 are separated by a narrow alley leading up to a small gate. Human remains were encountered both indoors and outdoors (Photograph: Sebastian Jakobsson).

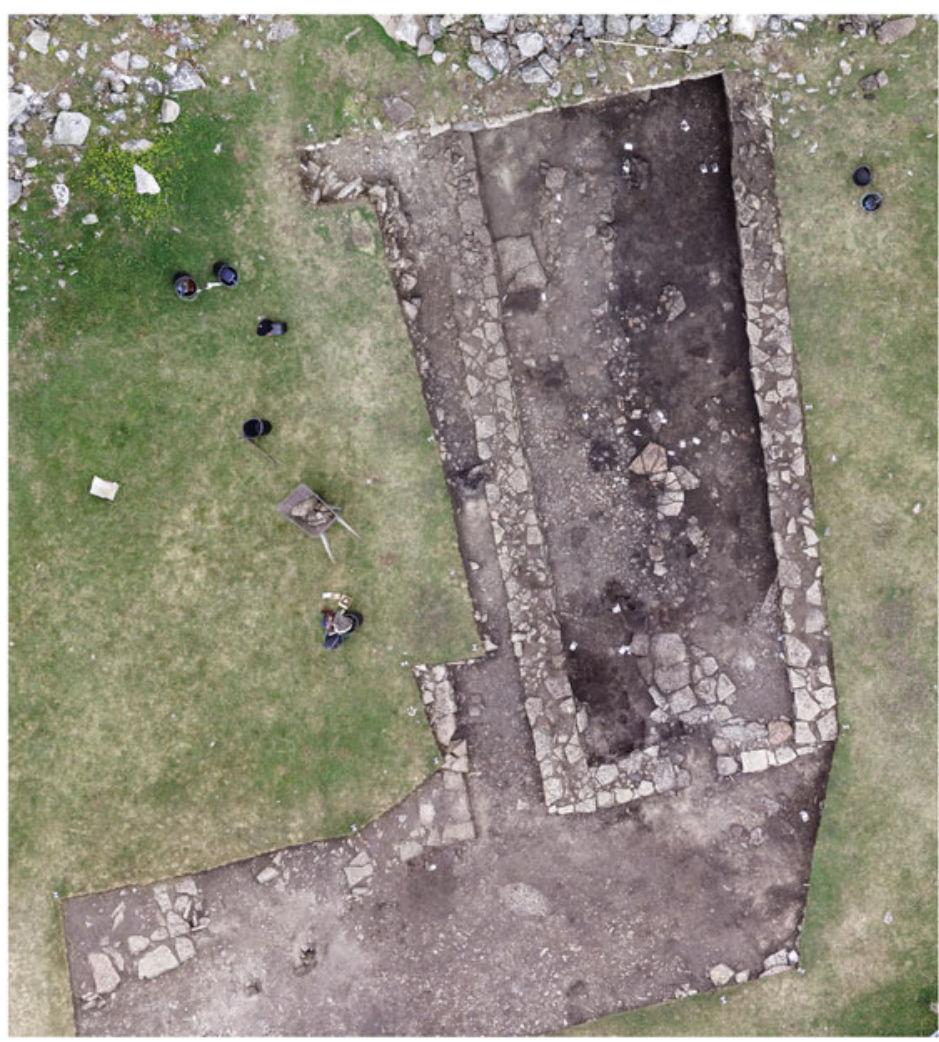

used throughout the year, seasonally, or just occasionally, but the fully excavated ringfort 'Eketorp' appears to have been in continual use (e.g. Skarin-Frykman 1967; Wegraeus 1976). The Öland ringforts were mainly inhabited during the Iron Age, but in some cases use extended into the early medieval era (e.g. Borg et al. 1976; Fallgren 2008; Herschend 1988; Näsman 2001, 93; Näsman \& Wegraeus 1979; Stenberger 1933).

Sandby borg has been subject to small-scale excavations by Kalmar County Museum since 2011.
The area investigated covers a modest 9 per cent of the entirety of the ringfort interior (Fig. 2b). The character of the finds does, however, allow insights into the ringfort's history. The artefacts encountered in Sandby borg have been typologically dated to the end of the fifth century, the so-called 'Migration period' (Fig. 3; Table 2). Traces of domestic life, such as the remains of craft items, remnants of cooking, food that was prepared but not consumed, and the (occasionally articulated) skeletons of domestic animals that died inside the ringfort have been uncovered 


\section{Clara Alfsdotter}

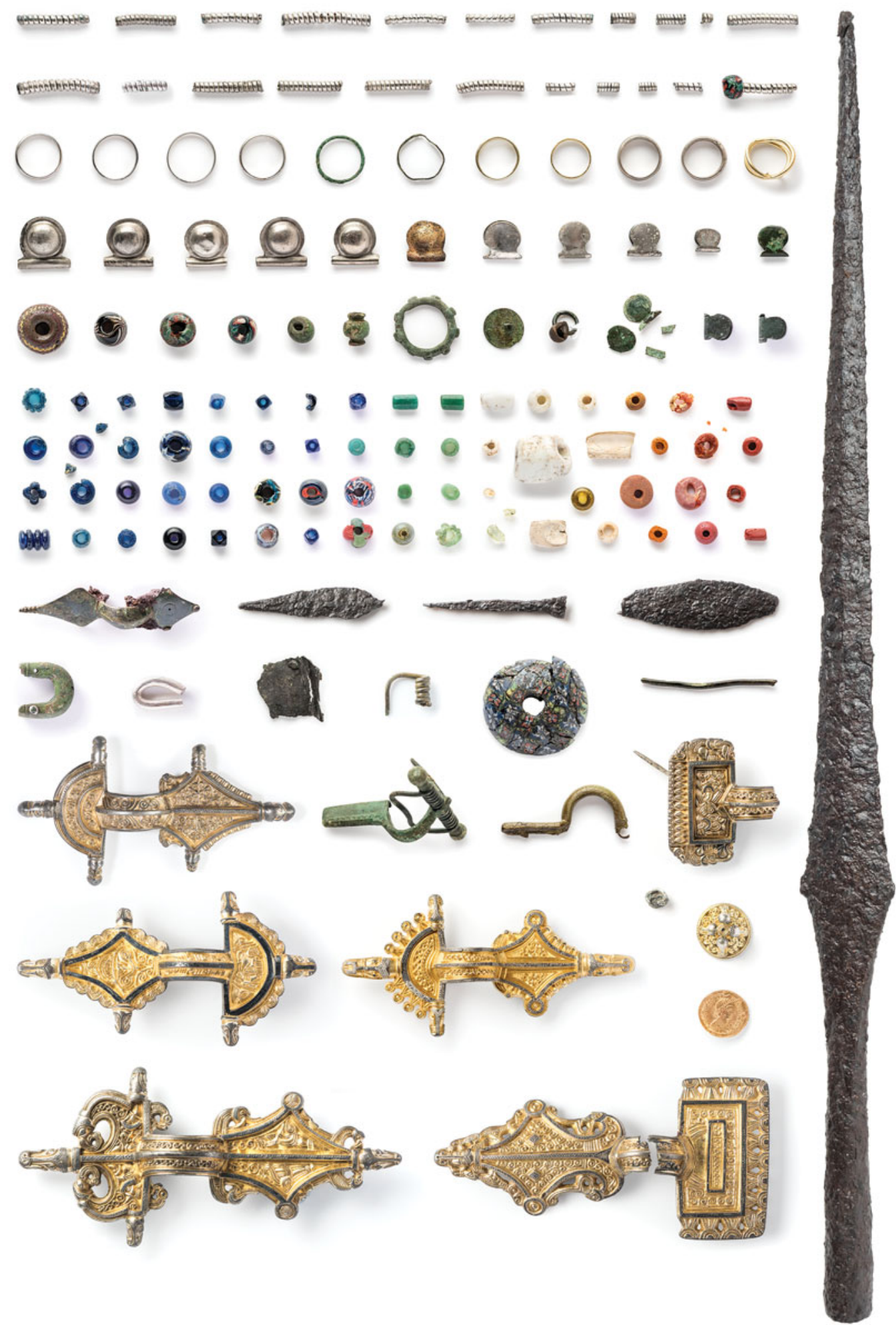

Figure 3. A selection of valuable artefacts encountered in Sandby borg, including relief brooches, glass beads, silver and gold finger rings, solidi and silver pendants. (Photograph: Daniel Lindskog.) 
Table 2. The table presents human remains that constitute unique individuals encountered in Sandby borg up to 2017 and based on analyses made by the author between 2014 and 2017. Bones that can derive from several individuals are not presented. Preservation of skeletons, demographic distribution, trauma and spatial context are accounted for $(A T=$ antemortem trauma; PT = perimortem trauma).

\begin{tabular}{|c|c|c|c|c|c|}
\hline ID & $\begin{array}{c}\text { Majority of skeleton articulated (schematic } \\
\text { percentage of skeleton preserved) }\end{array}$ & Age group (years) & Sex & Trauma & Context \\
\hline 1 & Yes (100) & Adolescent (17-19) & Male & $\mathrm{PT}+\mathrm{AT}$ & House 40 \\
\hline 2 & Yes (100) & Young Adult (19-25) & Male & $\mathrm{PT}$ & House 40 \\
\hline 3 & No (20) & Middle adult & $?$ & PT & House 40 \\
\hline 4 & Yes (75) & Young adult & Male? & $\mathrm{PT}+\mathrm{AT}$ & House 40 \\
\hline 5 & Yes (60) & Young(?) adult & Male & & House 40 \\
\hline 6 & Yes (90) & Adolescent (12-15) & $?$ & PT & House 40 \\
\hline 7 & Yes (100) & Adolescent (12-15) & $?$ & & House 40 \\
\hline 8 & No (5) & Infant/Child (2-5) & $?$ & & House 40 \\
\hline 9 & Yes (85) & Old Adult & Male & & House 52 \\
\hline 10 & No (5) & Infant & $?$ & & House 52 \\
\hline 11 & No (5) & Middle Adult & $?$ & & House 52 \\
\hline 12 & Yes (80) & Child (6-8) & $?$ & & House 4 \\
\hline 13 & No (40) & Adolescent (10-13) & $?$ & PT & House 4 \\
\hline 14 & No (20) & Old(?) Adult & $?$ & $\mathrm{PT}$ & House 4 \\
\hline 15 & No (75) & Old Adult & Male & & House 4 \\
\hline 16 & No (20) & Middle Adult & $?$ & & Street \\
\hline 17 & No (5) & Child (5-9) & $?$ & & Street \\
\hline 18 & No (30) & Young Adult (20-25) & $?$ & & Alley \\
\hline 19 & No (20) & Old Adult & Male & & Alley \\
\hline 20 & No (5) & Child (3.5-6.5) & $?$ & & Street \\
\hline 21 & No (25) & Adolescence (12-15) & $?$ & & Street \\
\hline 22 & No (5) & Child (3.5-6.5) & $?$ & & Street \\
\hline 23 & No (20) & Young Adult (20-25) & Male? & PT & Street \\
\hline 24 & No (20) & Middle Adult & Male & & House 3 \\
\hline 25 & No (5) & Infant (1.5-3 months) & $?$ & & House 40 \\
\hline 26 & No (5) & Infant (2-4) & $?$ & & House 3 \\
\hline
\end{tabular}

(Dutra Leivas \& Victor 2011; Gunnarsson et al. 2016; Papmehl-Dufay \& Alfsdotter 2016; Victor 2012; 2015; Victor et al. 2013). Valuable artefacts were also discovered, including silver relief brooches, glass beads, gold and silver finger rings, silver pendants and gold solidi (Fig. 3; Victor 2015). The artefacts are of both local and foreign manufacture, demonstrating regional and long-distance networks that include present-day Poland, the Baltic states and the Western Roman Empire (Fallgren \& Ljungkvist 2016; Victor 2015). There are strong regional similarities between the Sandby borg material culture and architecture and other Öland settlements, indicating that the people who inhabited Sandby borg were no strangers to the region. The artefacts found in Sandby borg imply that its inhabitants were influential actors in the local community (Victor 2015).
Human remains from a minimum of 26 individuals have been recovered, both from inside the remnants of houses and from the surrounding streets (Figs. 2 \& 4). Traces of lethal interpersonal violence (sharp, blunt and penetrating trauma) have been identified on several skeletons (Alfsdotter \& Kjellström 2018). The remains comprise individuals of all age groups, the youngest being less than three months old (Table 2). Although remains of an infant and finds of jewellery typical for the regional female attire have been discovered, the skeletons sexed so far do not display female sexual traits (Gunnarsson et al. 2016; Alfsdotter in press). The reason behind the absence of identified female remains is unknown. As half of the remains of individuals encountered were subadult, and many skeletons fragmentary (Table 2), there are several skeletons 


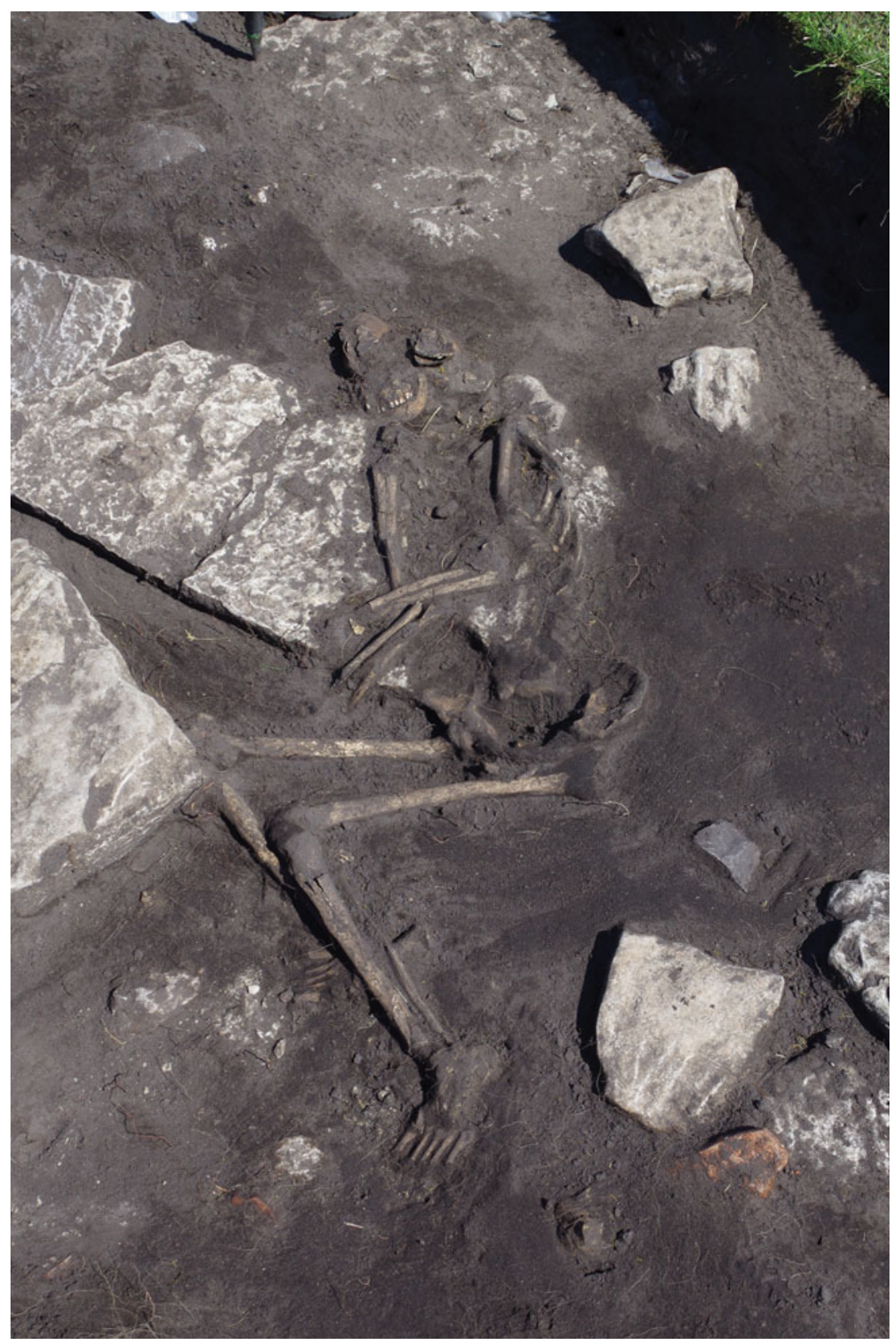

Figure 4. The skeleton of a young teen (ID7) during excavation, one of nine individuals whose remains were exhumed inside house 40. (Photograph: Kalmar County Museum.)

that have not been subject to osteological sex determination.

The handling of the dead in Sandby borg has been studied through taphonomic methods which led to conclusions of their peri- and postmortem fate (Alfsdotter \& Kjellström 2018; in preparation). The skeletal remains show differences in taphonomy; the majority were partly or fully articulated inside the houses and disarticulated on the street. The archaeothanatological analysis (Alfsdotter \& Kjellström in preparation) indicates that no manipulation of the remains took place following soft-tissue decomposition. The random positions of the skeletons (once corpses) suggest that the dead were left where they died without postmortem manipulation. One case is particularly indicative of a body being left where it fell. The articulated remains of an elderly man were found face down across the central hearth of one house. Parts of the frontal hip region of the skeleton were charred, indicating that the man fell across 


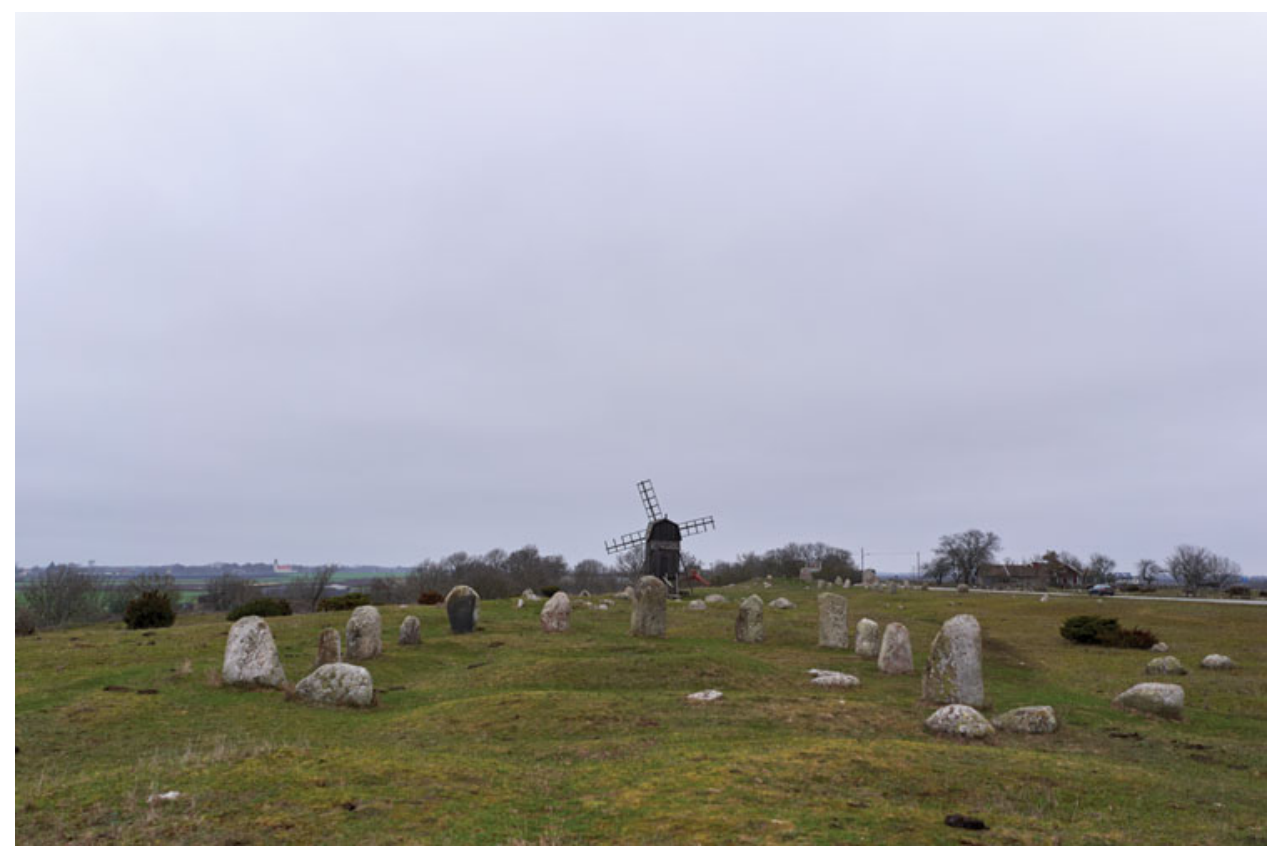

Figure 5. Gettlinge grave field, one of many Öland Iron Age grave fields with standing stones still visible today. (Photograph: Daniel Lindskog.)

the hearth while the hearth was still smouldering, and that his body was not moved thereafter (Alfsdotter et al. 2018; Papmehl-Dufay \& Alfsdotter 2016). The trauma pattern indicates that the victims were killed in an efficient manner, with a minimal amount of force (that is to say, with a few lethal blows, often directed to the cranium). There are no signs of excessive violence, i.e. mutilation (Alfsdotter \& Kjellström 2018). No defence injuries have been encountered. The victims seem to have been taken unawares and were ill prepared to defend themselves (Alfsdotter \& Kjellström 2018). The attackers were numerous, judging from the repeated pattern of lethal attacks evident in every house excavated so far. The dead bodies were neither heaped together nor buried. There are no indications that human trophies were taken. The minimum number of individuals per area excavated in Sandby borg is extensive and suggests that a majority of the dwellers (maybe all) were killed and left inside the ringfort without mortuary treatment (Victor 2015).

A sudden end to the activity inside the ringfort is demonstrated by still-articulated skeletal and macrobotanical remains (Alfsdotter et al. 2018; Heimdahl 2016). In contrast to other Öland ringforts, Sandby borg does not show traces of resettlement after the Migration period. The archaeological context shows that the material record in Sandby borg is contemporary with the assault that led to the deaths of the inhabitants (Alfsdotter et al. 2018).
The combination of considerable riches left in the Sandby borg dwellings, animals left behind, and the effective and indiscriminate killing (with regard to age) led to the hypothesis that the main objective of the attack was to kill, rather than to plunder (although the two are not mutually exclusive) (Alfsdotter et al. 2018; Alfsdotter \& Kjellström 2018; Victor 2015). Analyses of the archaeological context and human bones led to the conclusion that a massacre took place inside the ringfort, and that noone came to bury the dead (see Alfsdotter et al. 2018 for a more thorough discussion of the massacre hypothesis). The term 'massacre' is used in its broadest sense, referring to an act of intentional killing of a large number of people who were not prepared for battle, and the attack being carried by a group.

\section{Migration period Öland: land use and mortuary practice}

There are strong indications that the population of Öland grew during the early Iron Age, and that the island was densely populated in the Migration and Vendel periods (Beskow-Sjöberg 1977; 1987, 404; Fallgren 2006, 139-40; Herschend 1988; 1991, 43; Näsman 1988; 1994). During the latter Iron Age periods, even the poorest agricultural land was cultivated and the whole island colonized (e.g. Beskow-Sjöberg 1987, 108, 415; Fallgren 2006, 139-40,185; Näsman 1978). 
Grave fields have a long continuity on Öland, not seldom spanning the entire Iron Age (c. 500 BCAD 1050: Table 1) (e.g. Näsman 1994; Räf 2001; Wilhelmson 2017, 59). They are often marked with large erected stones and placed in clearly visible places in the landscape (Fig. 5). The grave fields were located in proximity to the settlements but away from the domestic sphere. Often, they were situated on the outskirts of a settlement, adjacent to the next village. The larger the settlement, the further away the grave field was situated (Fallgren 2006, 120f). Öland graves seem to have been strong territorial markers in the landscape (Fallgren 2006, 120, 137). Fallgren (like other researchers before him, cf. Brink 1994; Sundquist 2002; Zachrisson 1994, for discussions on the Swedish mainland) further discusses the Öland Iron Age marked grave fields as monuments through which land ownership, inheritance and genealogies were manifested (Fallgren 2006, 137).

Many of the excavated Öland Iron Age graves are dated to the early periods (e.g. Wilhelmson 2017) (Fig. 5; Table 1). A decline of dated burials from the Migration and Vendel period is contrasted by increased land use (Fallgren 2006, 139, 179). What was earlier interpreted as a population decrease during the Migration and Vendel period (Stenberger 1933), based on the few typologically dated graves, is now believed to be the result of a change in burial customs (e.g. Beskow-Sjöberg 1987, 108, 415; Fallgren 2006, 139,179; Näsman 1994). Fallgren $(2006,139)$ suggests that this change might be connected to intensified land use on Öland during the middle Iron Age. A fully colonized island would not have permitted new territorial expansion (as in the early Iron Age), restricting the capacity, opportunity and demand for new grave monuments. Subsequently, old graves may have been regularly re-used during the middle Iron Age, collective burials common, and the demand for new monumental structures decreased (Fallgren 2006, 138-40 Näsman 1994).

The normative treatment of the dead and mortuary beliefs Since the treatment of a corpse can only be understood in relation to the prevailing conceptions of the world, the normative regional treatment on Öland during the Iron Age is briefly presented (e.g. Robb 2013; Verdery 1999; Weiss-Krejci 2008; 2011; 2013). Inhumations of complete bodies and cremains were practised concurrently during the Iron Age (e.g. Beskow-Sjöberg \& Arnell 1987; Beskow-Sjöberg \& Hagberg 1991; 1996; Rasch 1991; 2001; Wilhelmson 2017). Inhumed human remains were often placed in stone or wooden cists, or in pits (often covered with stone slabs), and cremains in urns or unenclosed in pits or in cists (e.g. Rasch 1991). Both types of burials were sometimes set in larger outer structures such as cairns, mounds or stone paving (e.g. Rasch 1991; 1994; Wilhelmson 2017, 59). It is common to find several graves in the same outer stone structure surrounding the 'central grave', particularly cremains (e.g. Wilhelmson 2017, 58). Burials were either individual or collective (e.g. Räf 2001, 18; Rasch 1991; Sjøvold 1994). Secondary manipulation of skeletons is common, as evidenced by commingled, reduced and scattered remains (e.g. Rasch 1991; Sjøvold 1994; Wilhelmson 2017, 63), indicating a prolonged interaction with human remains. The burial customs are recognized from the southern Scandinavian mainland, but with a higher presence of complete body inhumations on Öland (e.g. Sjøvold 1994). Artefacts and animal remains occur in many graves, and are thought to be grave goods (e.g. Räf 2001; Rasch 1991; Sjøvold 1994). Iron Age grave goods can possibly be understood as a means to ease the journey to the next state of being (e.g. Johansson 2008; see also Van Gennep 1960). Looking at early medieval written sources about the Scandinavian Iron Age beliefs, there are strong indications that reincarnation after the earthly life was expected (e.g. Gansum 2008; Nordberg 2003; Rudebeck 2002).

\section{The treatment of the dead in Sandby borg}

The normative treatment of the dead in Migration period Öland included some kind of handling of the body during its liminal phase (predominantly cremation) and subsequent burial away from the domestic sphere. The non-handling of the bodies in Sandby borg presents a strong contrast to this. The absence of body processing is unique in the regional context as we know it. Interaction with the dead after skeletonizing was common practice during the Iron Age, but no such interaction is evidenced in Sandby borg. The corpses were left to decay in the domestic sphere. They were never recovered, nor given a burial or corporeal treatment. If one accepts that the moral obligation to perform passage rites for the dead extends beyond the most intimately bereaved, it would be expected that inhabitants of neighbouring villages would have felt obliged to tend to the dead, even if all Sandby borg inhabitants were in fact killed. Since Migration period Öland was densely populated (Fallgren 2006, 139, 179) it is unthinkable that the mass killing in Sandby borg went by unnoticed. The human remains left in Sandby borg seem to be the result of non-action 
and possible prevention of prescribed ritual. Had the ringfort inhabitants been killed during a raid by a foreign group, it would seem unlikely that the dead were not tended to, and that the land was not re-inhabited. Abandoning the ringfort seems to have been a conscious action, possibly a power demonstration by the (probably local) perpetrators (see also Alfsdotter et al. 2018; Victor 2015). In order to explore what the unburied corpses might have meant, and if they played a part as agents in the contemporary social transformation following the violent event, the social and emotional implications of the corpse is discussed below.

\section{Social response to death and postmortem agency}

Death always evokes emotions in the living, but the nature of these emotions varies in different cultures, as do the responses to the emotions (Tarlow 1999, 183). Although corpses and death are perceived in different ways, they universally require some form of action (Bloch \& Parry 1982; Nilsson Stutz 2003; 2008; Robb 2013). The handling and management of corpses is connected to social order and disorder and thus changes the social structure (e.g. Pérez 2012; Robben 2000). It is suggested that rituals related to someone's death need to be material, separate from the emotional and social crisis of someone's passing, in order to 'heal' the society (e.g. Aries 1981, 559-60). Through rituals connected to death, the corpse is often redefined by the mourners from a subject to an object that they can detach from, thus reinstituting social order through the construction of a 'proper death' during the liminal phase of the corpse (Hertz 1960; Nilsson Stutz 2003, 23; 2008; Nilsson Stutz \& Tarlow 2013; Van Gennep $1960,147)$. There is commonly a long period of interaction with the dead before the transition between different stages of being is complete (Robb 2013; Tarlow 1999; 2000; Van Gennep 1960; Weiss-Krejci 2011; 2013).

Nilsson Stutz argued (2003; 2014) that the human corpse is always handled in some culturally significant way. However, the choice not to handle the corpses in Sandby borg contrasts this supposition but is culturally significant as a negligence towards them. Since the dead in Sandby borg were not given a normative treatment during their liminal phase, it can be argued that the corpses never transitioned into objects that could be detached from the living society. A 'proper death' according to normative funeral practice was denied the Sandby borg inhabitants. As no proper deaths were given to the
Sandby borg victims, the social order was likely disturbed by that disregard for the corpses.

\section{Postmortem agency}

What might be the reasons for not granting someone a proper death? An essential question is what social impact a corpse may induce. Crandall and Martin (2014) discuss 'postmortem agency' as an important aspect of the holistic understanding of how corpses affect their surroundings. The corpse is, by some scholars, seen as a 'secondary actor' - an object that only extends the agency of other (living) actors (e.g. Harper 2010; Tung 2014). Others claim that the corpse can be a 'primary actor' that through its very presence can affect the emotions of the living (e.g. Crandall \& Harrod 2014; Gell 1998; Novak 2014). In line with the latter, Robb $(2004 ; 2013)$ argues that dead bodies can exercise agency because they initiate actions. Human remains primarily affect their surroundings during their liminal phase (e.g. Hertz 1960). If the mortuary treatment is properly conducted, the potential power of the human remains as agents in society is often reduced. The grief and emotional crisis of the missing subject does not necessarily end with the completion of a 'proper death' through the prescribed rite of passage, but the agency of the corpse (or skeleton) as both a primary and secondary actor is in many belief systems limited following a proper death. Given that the success or failure of rites of passage is not only dependent on the materiality of the corpse (as a primary actor), but also on the performance of the living collective (those who must live with the outcome of the passage rite), both the potential primary and secondary postmortem agencies seem to be closely connected. Analysing the Norse sagas, Gansum (2008) argues that the dead could hold agency in the Scandinavian Iron Age, and that potential postmortem agency was closely connected to social (dis)order. Revenants had their own agenda, often contrasting with that of the living. One example was a man who died with a grudge in his home, after which he had to be carried out through a hole in a wall to prevent him coming back through the door. Nevertheless, he came back to the living to claim lives of individuals that would accompany him in death. In order to stop the revenant, the grave was reopened after a year to move the deceased to another location, only to find the body of the man undecayed (Gansum 2004; 2008). The sagas cannot be read as objective truths about the Scandinavian Iron Age, but this example illustrates the complexity built into how postmortem agency could be perceived. The agency of dead spirits 
seems to have been connected to the dead body, and thus the ability to interfere with living society was connected to the corporeal fate (Gansum 2008).

Postmortem agency is evident in many different settings, due to various causes and with different outcomes. The agency is often powerful in cases where human remains have not been given a proper death, and thus never turn into objects that can be detached from living society (cf. Hertz 1960). The dead can be left in the liminal phase on purpose, like Lenin in his mausoleum, or unintentionally, such as human remains not being relocated after lethal catastrophes. Individuals left in the liminal phase are not necessarily controversial or problematic in living society. An example of such a case is the relics of saints. Other forms of postmortem agency are unwished for by the collective. One historic example is that if people believed that the dead might rise again as vampires, the rite of passage needed to be altered to prevent them from doing so (Betsinger \& Scott 2014). A third form of postmortem agency is when the agency of human remains is used for the benefit of one group in society at the expense of another. The latter is common in conflicts, where human remains can exert agency both by their presence and by their absence. Contemporary examples are political conflicts where corpses 'disappear' (for example in Argentina: e.g. Brysk 1994; Robben 2000), or when burials are not the result of proper mortuary rites, such as mass graves following genocides or civil wars (e.g. Klintenberg 2001; Renshaw 2011; Wagner 2008). Thus, a burial does not necessarily mean that a proper death has taken place. The dead can be buried but still be in the liminal phase due to insufficient mortuary treatment. One example illustrating this is the recent exhumations of the Spanish civil war victims that were buried in mass graves. Even though the killings took place $c$. 70 years prior to the exhumations, the main rationale behind the excavations was that the dead, and the treatment of their remains, still affected the living through a perceived bond with them (Renshaw 2011, 31).

The advantage of corpses as meaning-bearers over living bodies is that corpses have no agenda of their own. There is symbolic power in the ambiguity of the corpse and thus it is able to evoke different understandings. Dead bodies are ideal as conveyors of meaning, since they influence kinship, death and life, history, authority, identity, proper death, morality, territory and time (Verdery 1999). The materiality of the body or the skeleton is crucial to its symbolic power. They can be moved and displayed in ways that intangible notions cannot. Corporeality is important when claiming territory and supremacy
(Verdery 1999, 27-33, 109-10), as can be seen in archaeological examples where geographical entitlement is often claimed through ancestral burials and reburials (e.g. Artelius 2004; Fahlander 2016; Fallgren 2006; Hållans Stenholm 2012; Holtorf 1996; Pedersen 2006; Thäte 2007; Zachrisson 1994).

The dead body is easy to relate to emotionally since everyone is (or has) a body (Verdery 1999). Even those long dead and unknown to living humans can evoke emotional responses, likely a result of the connection with personal losses or identification with parts of the deceased person's biography (Verdery 1999). Given that corpses are effective agents, they are potentially an important means of bringing 'symbolic capital' to social transformation. Verdery (1999) explored the corpse as a political symbol from an anthropological perspective. She argues that the fear and anxiety invoked by death, and the essential question of the meaning of life, makes corpses perfect to use as agents in times of major social disruption. Not only can the politicization of corpses be applied to transform the future of a society, but also to rewrite the past (e.g. Renshaw 2011, 27, 32-4; Verdery 1999, 28-31).

\section{Postmortem agency in relation to lethal inter-group conflict and 'bad death'}

The theoretical concept of 'politicization of the dead' was introduced to bioarchaeology by Pérez (2012). The theories presented by Pérez are in line with those discussed by Verdery (1999). Essential to the politicization of the dead is the corpse as a transitional object for both the perpetrators and the defeated (Pérez 2012; Robben 2000, 85). Inspired by Robben (2000), Pérez (2012) argued that collective violence involves complex socio-cultural factors that interlink political, economic and psychological elements. Hence, collective lethal violence does not 'only' cause corporeal deaths and physical trauma, but it also affects the psyche and the future of the society in which it takes place (e.g. Daniel 1996; Feldman 1991; Nordstrom \& Martin 1998; Pérez 2012; Robben 2000; Suárez-Orozco \& Robben 2000). Violence can work as both a stabilizing and a destabilizing social tool (e.g. Galtung 1990; Kurtz \& Turpin 1997; Sluka 1992) and can even facilitate social cohesion through the creation and destruction of 'the other' (Krohn-Hansen 1994; Rappa 1999; Osterholtz 2012; Schmidt \& Schröder 2001). In order to analyse and understand the performance of violence better, the perspectives of the perpetrator(s), the witness(es) and the victim(s) all needs to be incorporated (Krohn-Hansen 1994; Riches 1986; 
Whitehead 2004; 2005). Osterholtz (2012) drew on this line of research when contextualizing osteological evidence of torture and hobbling from the Sacred Ridge Site, Colorado (for other examples of bioarchaeological research incorporating politicization of corpses, see Novak 2014; Tung 2014). Osterholtz (2012) discussed how social control can be gained over both witnesses and victims of direct violence by exercising performative violence against only a limited number of individuals. This is because the threat of violence is equally as powerful as direct violence (Ferguson 2008; Krohn-Hansen 1994; Parsons 2007). Consequently, social control can be imposed on a large number of people by a relatively limited number of enforcers, if one establishes a credible threat of violence (Osterholtz 2012). Osterholtz concludes that:

When expressed physically, structural violence is a group performative action where the impact is greater than the actual action perpetrated. Witnesses are invisible in the archaeological record, but the fact that this deposition [the human remains showing traces of torture] occurred near or at the time of abandonment of the site may suggest that the act had long-reaching consequences for the area. (Osterholtz 2012, 134)

Applying this line of reasoning to the Sandby borg site, the 'witnesses' would mainly have been the inhabitants of neighbouring settlements (and any potential survivors from Sandby borg). It is, however, unlikely that people that lived in the surrounding area witnessed the actual attack on Sandby borg. Whitehead (2004) argued that 'witnesses' to violence are all those to whom the violence is reproduced or retold. It is reasonable to interpret the negligence to conduct proper rites of passage for those that died in Sandby borg and the abandonment of the settlement as a manifestation of the social control exercised by the perpetrating group. The violent performance could have served as a form of deterrent, or example serving to reinforce social control over the local populace.

Most mass killings, both modern and in the distant past, are followed by some form of inhumation of the corpses, whether in mass graves dug by the assailants to prevent the spreading of diseases, or combined with mortuary practices by supporters in order to produce a proper death. Manipulation of corpses connotes political symbolism and thus impacts both contemporary and future societies and the creation of spatial and collective memory (Douglas 1966, 115; Pérez 2012; Renshaw 2011, 27; Verdery 1999, 3). Viewing what transpired in Sandby borg in the light of these perspectives, the unburied corpses may have functioned as playing pieces in a pursuit of outcomes beyond the actual attack itself, such as a change of the collective memory, territorial conquest and a stigmatization of the victims. Returning to the suggestion by Fallgren (2006, 120, 137), that the Öland Iron Age graves carry symbolic power as landscape markers for territory and inheritance, it is reasonable to argue that an active decision not to bury the dead in Sandby borg could have been a means to break the genealogy of the Sandby borg inhabitants, and thus their territorial claim. A discontinuation of their grave field and the killing of the settlers might have granted the attackers a possibility to expand, make new territorial claims and increase their local influence.

Denial of proper passage rites is often inflicted on those who have suffered a 'bad death' (e.g. Weiss-Krejci 2013). Inspired by Thomas (1975, 192), Bloch and Parry (1982) defined a 'bad death' as a death not leading to regeneration due to the lack of social control. Drawing on anthropological research, Weiss-Krejci wrote that:

Improper or disrespectful treatment can serve as a means to punish or destroy a person, demonstrate religious and political power, or simply to avert the dangerous dead. In this sense, the unburied dead are often deviant social personae, political enemies, and people who have died a bad death. (Weiss-Krejci 2013, 281)

Given the indiscriminate killing in Sandby borg, all the victims were probably not social outcasts in Migration period Öland. Based on the discussion put forward here, a more likely explanation is that a local political conflict was the cause for the killing. People who die violently are often refused mortuary treatment (Tylor 1903, 27-8). Deprivation of proper mortuary treatment of enemies commonly brings shame and humiliation to the conquered (Houston et al. 2006, 203). In many belief systems, corpses of people that are not given proper rites of passage haunt the living and are refused entry into the afterlife, their souls condemned to live on the margins between this life and the next as some form of malignant spirits (Hertz 1960; Tylor 1903, 27-30; Van Gennep 1960, 160-61; Weiss-Krejci 2013). Relating back to the Norse sagas and the lack of normative treatment of the dead in Sandby borg, the fact that the corpses were left in their homes without mortuary treatment makes a strong case for possible postmortem agency and a bad death. 


\section{Discussion}

As Robb (2013) pointed out, deprivation of burial is stigmatizing only if a culture believes that the body is important in death, and since Migration period deaths often involved extensive rites of passage, the body was indeed an important aspect in contemporary death rituals. Given the non-handling of the Sandby borg victims, it is reasonable to argue that they suffered a bad death. If a bad death is in fact inflicted on those who are killed beyond social control, perhaps the violence in Sandby borg was not uniformly sanctioned by society, but was the result of actions conducted by a rebelling group. Perchance neighbours were either prevented from burying the dead, or the very fact that they suffered a bad death led to an unwillingness to handle the corpses. The deprivation of a proper death probably led to shame, disgrace, prevention of regeneration and thus an eternal separation from the living. Leaving the Sandby borg victims unburied can be seen as an aggressive social action, a final act of violence and punishment against the dead.

Leaving the corpses unburied would have made it easy to manifest certain aspects of the biography and memory of the once living (Verdery 1999). Their bad deaths likely came to dominate their entire remembrance (whereas funerary rites often commemorate several aspects of the once living). A proper death will turn the dead into something new (i.e. ancestors), but the unburied dead are left stranded in this world, without regeneration. Indeed, even today, as the remains of Sandby borg are unearthed after 1500 years, the biography of the Sandby borg dwellers is still dominated by their deaths.

Returning to Verdery and the political lives of dead bodies, corpses can be used as instruments to achieve various political goals, such as the justification of certain actions, territorial claims, asserting jurisdiction, or disputing the authority of others (Verdery 1999). These considerations might have been key factors in the event that occurred in Sandby borg. The assault was likely part of a local power play during the politically turbulent Migration period (cf. Alfsdotter et al. 2018; Victor 2015; for Migration period context, cf. Fagerlie 1967; Hedeager 1992; 2011, 170; Herschend 1980; Høilund Nielsen 2005; Stenberger 1933). Metaphorically speaking, the dead bodies bore witness to the end of life inside the ringfort and thus the extinction of networks, wealth, land and power connected to Sandby borg. With regard to the corpse as secondary actor-extending the agency of living actors- the unburied corpses can be explored through the perspective of the perpetrators and the witnesses.
On the premise that the inhabitants of Sandby borg were in some position of power, killing them and denying their corpses mortuary treatment would have granted their conquerors power and dominance in the area. The death of the ringfort community would have changed both the physical and the mental landscape, perhaps allowing the enemy to redraw the political landscape as part of a social transformation achieved through violent dominance. The massacre was likely a means to spread terror and manifest power among the witnesses.

The stigmatization of the Sandby borg inhabitants might soon have led to a taboo in contemporary society due to their bad deaths. Perhaps the reason that Sandby borg was not re-inhabited was the stigmatization that changed both past and future perceptions of Sandby borg, along with a change in territorial claims. The sensory response of possible visitors, or simply the knowledge of the presence of the unburied dead within the ringfort, would have made the corpses primary actors through their mere existence (e.g. Crandall \& Harrod 2014; Gell 1998; Novak 2014; Robb 2013). The denial of rites of passage might have resulted in the inhabitants of Sandby borg being eternally trapped in a liminal phase of existence, a condition which exerted agency among witnesses in contemporary society.

\section{Conclusion}

The inclusion of social theories in the investigation of human remains from violent encounters makes it possible to move beyond merely recording the remains of the dead in terms of their demography, their skeletal trauma and clues about life history, and generate a deeper understanding of how collective violence can be organized to achieve consequences beyond the violence itself. With the Sandby borg massacre as a case study, I have investigated how the perspective of the perpetrators, victims and witnesses can be explored in relation to postmortem agency in cases of lethal inter-group violence. This paper demonstrates an example of how socially transformative outcomes of proper and bad death can be studied in the deeper past.

The corpse carries strong political and symbolic capital and is therefore useful in the process of social change. Corporeal death commonly demands a social response. The response in the case of the Sandby borg massacre, where the victims were not cared for, was probably one of horror. The gain for the perpetrators was likely political power through a redrawing of the biography of the victims, the political landscape and the spatial memory, thus 
changing both the past and the future. The denial of rites of passage might have led to eternal separation between the dead and their sympathizers and the end of regeneration for the defeated. Sandby borg was seemingly left as a monument of terror.

\section{Acknowledgements}

I am very grateful to the editor and to the anonymous reviewers for their help in improving this paper. Many thanks to Anders Högberg, Liv Nilsson Stutz and Cornelius Holtorf for constructive feedback on previous versions of the manuscript. Thank you Delia Ní Chíobhaín Enqvist and Dejan Gajic for revising the English. For help with figures and pictures, I thank Helena Victor, Daniel Lindskog, Jhonny Therus and Sebastian Jakobsson.

\section{Clara Alfsdotter Linnaeus University School of Cultural Studies Faculty of Art and Humanities Linnégatan 5 SE-391 82 Kalmar Sweden}

Email: Clara.Alfsdotter@bohuslansmuseum.se

\section{References}

Alfsdotter, C., L. Papmehl-Dufay \& H. Victor, 2018. A moment frozen in time: evidence of a late fifth-century massacre at Sandby borg. Antiquity 92, 421-36.

Alfsdotter, C., in press. Humanosteologi, in Sandby borg IX. Undersökningar 2016. Sandby socken, Mörbylånga kommun, Öland, eds. L. Papmehl-Dufay \& H. Victor. Report prepared for Kalmar läns museum

Alfsdotter, C. \& A. Kjellström, 2018. The Sandby borg massacre: interpersonal violence and the demography of the dead. European Journal of Archaeology. doi:10.1017/eaa.2018.55

Alfsdotter, C. \& A. Kjellström, in preparation. A taphonomic interpretation of the postmortem fate of the victims following the mass killing at Sandby borg.

Anstett, E. \& J-M. Dreyfus, 2014. Introduction. Corpses and mass violence: an inventory of the unthinkable, in Human Remains and Mass Violence: Methodological approaches, eds. E. Anstett \& J-M. Dreyfus. Manchester: Manchester University Press, 1-11.

Aries, P., 1981. The Hour of Our Death. New York (NY): Alfred A. Knopf.

Artelius, T., 2004. Halländsk rösekuliss med stenbåt och bålplats. (Halland, Stråvalla socken, Stråvalla-strand 2:29, RA ̈̈ 23.) Göteborg: Riksantikvarieämbetet.
Beskow-Sjöberg, M., 1977. The Archaeology of Skedemosse 4. The Iron Age settlement of the Skedemosse area on Öland, Sweden. Stockholm: Kungliga Vitterhetsakademien.

Beskow-Sjöberg, M., 1987. Sammanfattande kommentarer och analys, in Ölands Järnåldersgravfält. Volym I, Alböke, Köpings, Räpplinge, Löts, Egby, Bredsätra och Gärdslösa socknar, eds. M. Beskow-Sjöberg \& H. Arnell. Stockholm: Riksantikvarieämbetet och Statens historiska museer, 418-33.

Beskow-Sjöberg, M. \& H. Arnell (eds.), 1987. Ölands Järnåldersgravfält. Volym I, Alböke, Köpings, Räpplinge, Löts, Egby, Bredsätra och Gärdslösa socknar. Stockholm: Riksantikvarieämbetet och Statens historiska museer.

Beskow-Sjöberg, M. \& U.E. Hagberg (eds.), 1991. Ölands Järnåldersgravfält. Volym II, Högsrum, Glömminge, Algutsrum, Torslunda, Långlöt, Runsten, Norra Möckleby och Gårdby. Stockholm: Riksantikvarieämbetet och Statens historiska museer.

Beskow-Sjöberg, M. \& U.E. Hagberg (eds.), 1996. Ölands järnåldersgravfält. Volym III, Vickleby, Resmo, Mörbylånga, Kastlösa, Sandby, Stenåsa och Hulterstad. Stockholm: Riksantikvarieämbetet och Statens historiska museer.

Betsinger, T., \& A. Scott, 2014. Governing from the grave: vampire burials and social order in post-medieval Poland. Cambridge Archaeological Journal 24(3), 467-76.

Bloch, M. \& J. Parry, 1982. Introduction: death and the regeneration of life, in Death and the Regeneration of Life, eds. M. Bloch \& J. Parry. Cambridge: Cambridge University Press, 1-44.

Borg, K., U. Näsman \& E. Wegraneus (eds.), 1976. Eketorp. Fortification and settlement on Öland/Sweden. The monument. Stockholm: Royal Academy of Letters, History and Antiquities.

Brink, S., 1994. En vikingatida storbonde i södra Norrland. Tor 26, 145-62.

Brysk, A., 1994. The politics of measurement: the contested count of the disappeared in Argentina. Human Rights Quarterly 16(4), 676-92.

Crandall, J.J. \& R. Harrod, 2014. Ghostly gunslingers: the postmortem lives of the Kiel brothers, Nevada's first frontiersmen. Cambridge Archaeological Journal 24(3), 487-97.

Crandall, J.J. \& D.L. Martin, 2014. The bioarchaeology of postmortem agency: integrating archaeological theory with human skeletal remains. Cambridge Archaeological Journal 24(3), 429-35.

Daniel, E.V., 1996. Charred Lullabies - Chapters in an anthropology of violence. Princeton (NJ): Princeton University Press.

Douglas, M., 1966. Purity and Danger: An analysis of the concepts of pollution and taboo. London: Routledge \& Kegan Paul.

Dutra Leivas, I. \& H. Victor, 2011. Sandby borg I. Undersökningar 2011. Sandby socken, Mörbylånga kommun, Öland. Kalmar: Kalmar läns museum.

Fagerlie, J.M., 1967. Late Roman and Byzantine solidi found in Sweden and Denmark. (Numismatic notes and 
monographs 157). New York (NY): American Numismatic Society.

Fahlander, F., 2016. The materiality of the ancient dead. Post-burial practices and ontologies of death in southern Sweden AD 800-1200. Current Swedish Archaeology 24, 137-62.

Fallgren, J-H., 2006. Kontinuitet och förändring. Bebyggelse och samhälle på Öland 200-1300 e Kr. [Settlement and society on Öland 200-1300 AD]. (AUN 35.) Uppsala: Uppsala University.

Fallgren, J-H., 2008. Fornborgar, bebyggelse, och odlingslandskap, in Gråborg på Öland, ed. G. Tegnér. Stockholm: Kungliga Vitterhetsakademien, 119-47.

Fallgren, H. \& J. Ljungkvist, 2016. The ritual use of brooches in early medieval forts on Öland, Sweden. European Journal of Archaeology 19(4), 1-23.

Feldman, A., 1991. Formations of Violence - The narrative of the body and political terror in Northern Ireland. Chicago (IL): University of Chicago Press.

Ferguson, B., 2008. Ten points of war. Social Analysis 52(2), 32-49.

Galtung, J., 1990. Cultural violence. Journal of Peace Research 27(3), 291-305.

Gansum, T., 2004. Hauger som konstruksjoner - Arkeologiske forventninger gjennom 200 år. (Gotars Serie B. No. 33.) Göteborg: University of Gothenburg.

Gansum, T., 2008. Reproduction and relocation of death in Iron Age Scandinavia, in The Materiality of Death: Bodies, burials, beliefs, eds. F. Fahlander \& T. Oestigaard. Oxford: British Archaeological Reports, 141-6.

Gell, A., 1998. Art and Agency: An anthropological theory. Oxford: Clarendon Press.

Gunnarsson, F., H. Victor \& C. Alfsdotter, 2016. Sandby borg VII. Undersökningar 2015. Sandby socken, Mörbylånga kommun, Öland. Kalmar: Kalmar läns museum.

Hållans Stenholm, A-M., 2012. Fornminnen: Det förflutnas roll $i$ det kristna och förkristna Mälardalen. Lund: Nordic Academic Press.

Harper, S.A., 2010. The social agency of dead bodies. Mortality 15(4), 308-22.

Hedeager, L., 1992. Iron-Age Societies. Oxford: Basil Blackwell.

Hedeager, L., 2011. Iron Age Myth and Materiality. An archaeology of Scandinavia AD 400-1000. Abingdon/ New York (NY): Routledge.

Heimdahl, J., 2016. Växtmakrofossilanalyser, in Sandby borg V. Seminariegräuning 2014. Sandby socken, Mörbylånga kommun, Öland, eds. L. Papmehl-Dufay \& C. Alfsdotter. Kalmar: Kalmar läns museum, 50-51.

Herschend, F., 1980. Myntat och omyntat guld. Två studier I öländska guldfynd. Uppsala: Gustavianum.

Herschend, F., 1988. Bebyggelse och folkvandringstid på Öland, in Folkevandringstiden i Norden. En krisetid mellem xldre og yngre jernalder, eds. U. Näsman \& J. Lund. Aarhus: Aarhus Universitetsforlag, 43-67.

Herschend, F., 1991. Om öländsk metallekonomi i första hälften av första årtusendet e.Kr., in
Samfundsorganisation og Regional Variation. Norden $i$ Romersk Jernalder og Folkevandringstid, eds. C. Fabech \& J. Ringtveg. (Jysk Arkæologisk Selskabs Skrifter 27.) Aarhus: Aarhus Universitetsforlag, 33-46.

Hertz, R., [1907] 1960. Death $\mathcal{E}$ The Right Hand (trans. R. Needham \& C. Needham). Glencoe (IL): Free Press.

Holtorf, C., 1996. Towards a chronology of monuments: understanding monumental time and cultural memory. Journal of European Archaeology 4, 119-52.

Houston, S., K.A. Taube \& D. Stuart, 2006. The Memory of Bones: Body, being, and experience among the Classic Maya. Austin (TX): University of Texas Press.

Høilund Nielsen, K., 2005. '... the sun was darkened by day and the moon by night ... there was distress among men ...' - on social and political development in 5th- to 7th-century southern Scandinavia. Studien zur Sachsenforschung 15, 247-86.

Johansson, A., 2008. A road for the Viking's soul, in The Materiality of Death: Bodies, burials, beliefs, eds. F. Fahlander \& T. Oestigaard. Oxford: British Archaeological Reports, 147-50.

Klintenberg, E., 2001. Bodies that don't matter: death and dereliction in Chicago. Body and Society 7(2-3), 121-36.

Knüsel, C. \& M.J. Smith (eds.), 2014. The Routledge Handbook of the Bioarchaeology of Human Conflict. London/New York: Routledge.

Krohn-Hansen, C., 1994. The anthropology of violent interaction. Journal of Archaeological Research 50(4), 367-81.

Kurtz, L.R. \& J. Turpin, 1997. Conclusion: untangling the web of violence, in The Web of Violence: From interpersonal to global, eds. J. Turpin \& L.R. Kurtz. Urbana (IL): University of Illinois Press, 207-32.

Martin, D.L., R.P. Harrod \& V.R. Pérez (eds.), 2012. Bioarchaeology and the study of violence, in The Bioarchaeology of Violence, eds. D.L. Martin, R. P. Harrod \& V.R. Pérez. Gainesville (FL): University Press of Florida, 1-10.

Näsman, U., 1978. Öland, Eketorp and the transition between the Montelii periods VI and VII. Tor 17, 1975-76, 335-61.

Näsman, U., 1988. Den folkvandringstida ?krisen i Sydskandinavien, in Folkevandringstiden $i$ Norden. En krisetid mellem xldre og yngre jernalder, eds. U. Näsman \& J. Lund. Aarhus: Aarhus Universitetsforlag, 187-227.

Näsman, U., 1994. The Iron Age graves on Öland - representative of what?, in Prehistoric Graves as a Source of Information, ed. B. Stjernquist. Symposium as Kastrlösa, Öland, May 21-23, 1992. (Konferenser 29.) Stockholm: Kungl. Vitterhets Historie och Antikvitets Akademien, 15-31.

Näsman, U., 2001. Tabell över Ölands fornborgar, in Ölands Guldålder: romersk järnålder och folkvandringstid med en liten öländsk historiebok: en studieguide, ed. G. Aldestam. Kalmar: Kalmar läns museum, 93.

Näsman, U. \& E. Wegraeus (eds.), 1979. Eketorp. Fortification and settlement on Öland/Sweden. The 
setting. Stockholm: Royal Academy of Letters, History and Antiquities.

Nilsson Stutz, L., 2003. Embodied Rituals and Ritualized Burials. Tracing ritual practices in Late Mesolithic burials. (Acta Archaeologica Lundensia Series in $8^{\circ} 46$.) Stockholm: Almqvist \& Wiksell.

Nilsson Stutz, L., 2008. More than metaphor: Approaching the human cadaver in archaeology, in The Materiality of Death - Bodies, Burials, Beliefs, eds. F. Fahlander \& T. Oestigaard. Oxford: British Archaeological Reports, 19-28.

Nilsson Stutz, L., 2014. A proper burial: some thoughts on changes in mortuary ritual, and how archaeology can begin to understand them, in Death and Changing Rituals: Function and meaning in ancient funerary practices, eds. R. Brandt, M. Prusac \& H. Roland. Oxford: Oxbow, 1-16.

Nilsson Stutz, L. \& S. Tarlow, 2013. Beautiful things and bones of desire: emerging issues in the archaeology of death and burial, in The Oxford Handbook of the Archaeology of Death and Burial, eds. L. Nilsson Stutz \& S. Tarlow. Oxford: Oxford University Press, 1-14.

Nordberg, A., 2003. Krigarna i Odins sal: Dödsföreställningar och krigarkult $i$ fornnordisk religion. Stockholm: Stockholm University.

Nordstrom, C. \& J. Martin, 1998. Deadly myths of aggression. Journal of Aggressive Behavior 24(2), 147-59.

Novak, S.A., 2014. How to say things with bodies: meaningful violence on an American frontier, in The Routledge Handbook of the Bioarchaeology of Human Conflict, eds. C Knüsel \& M. Smith. New York (NY): Routledge, 524-59.

Osterholtz, A.J., 2012. Hobbling and torture as performative violence: an example from the prehistoric Southwest. Sandby socken, Mörbylånga kommun, Öland. Kalmar: Kalmar läns museum.

Papmehl-Dufay, L. \& C. Alfsdotter (eds.), 2016. Sandby borg V. Seminariegrävning 2014. Sandby socken, Mörbylånga kommun, Öland. Kalmar: Kalmar läns museum.

Parsons, K., 2007. Structural violence and power. Peace Review: A Journal of Social Justice 19, 173-81.

Pedersen, A., 2006. Ancient mounds for new graves: an aspect of Viking Age burial customs in Southern Scandinavia, in Old Norse Religion in Long-Term Perspectives: Origins, changes and interactions, eds. A. Andrén, K. Jennbert \& C. Raudvere. Lund: Nordic Academic Press, 346-53.

Pérez, V.R., 2012. The politicization of the dead: violence as performance, politics as usual, in The Bioarchaeology of Violence, eds. D.L. Martin, R.P. Harrod \& V. R. Pérez. Gainesville (FL): University Press of Florida, 13-28.

Räf, E., 2001. Krumknivar, kvinnor och kreatur. Aspekter på kvinnligt genus under äldre järnålder på Öland; Vad spelar djuren för roll? Om djur i öländska gravar från äldre järnålder. (Report Series 79-80.) Lund: Lund University.

Rappa, A.L., 1999. Imprisoning the other. Peace Review: A Journal of Social Justice 11(1), 157-9.
Rasch, M., 1991. Kan gravseden spegla social och politisk utveckling? En närstudie av ett stort arkeologiskt material från en liten ö, in Samfundsorganisation og Regional Variation. Norden i romersk jernalder og folkevandringstid, eds. C. Fabech \& J. Ringtveg. (Jysk Arkæologisk Selskabs Skrifter 27.) Aarhus: Aarhus Universitetsforlag, 133-40.

Rasch, M., 1994. Burial practices - grave furniture and burial methods during the Roman Iron Age, in Prehistoric Graves as a Source of Information, ed. B. Stjernquist. Symposium as Kastrlösa, Öland, May 21-23, 1992. (Konferenser 29.) Stockholm: Kungl. Vitterhets Historie och Antikvitets Akademien, 181-201.

Rasch, M. (ed.), 2001. Ölands järnåldersgravfält, IV Böda, Högby, Källa, Persnäs, Föra, Smedby, Södra Möckleby, Ventlinge, Segerstad, Gräsgård och Ås. Stockholm: Riksantikvarieämbetet och Statens historiska museer.

Renshaw, L., 2011. Exhuming Loss: Memory, materiality and mass graves of the Spanish civil war. (Critical Cultural Heritage Series 6.) Walnut Creek (CA): Left Coast Press.

Riches, D. (ed.), 1986. The Anthropology of Violence. Oxford: Blackwell.

Robb, J., 2004. The extended artefact and the monumental economy: a methodology for material agency, in Rethinking Materiality: The engagement of mind with the material world, eds. C. Gosden, C. Renfrew \& E. DeMarrais. Cambridge: McDonald Institute for Archaeological Research, 131-9.

Robb, J., 2013. Creating death: an archaeology of dying, in The Oxford Handbook of Death and Burial, eds. L. Nilsson Stutz \& S. Tarlow. Oxford: Oxford University Press, 441-56.

Robben, A.C.G.M., 2000. The assault of basic trust: disappearances, protest and reburial in Argentina, in Cultures under Siege: Collective violence and trauma, eds. M.M. Suárez-Orozco \& A.C.G.M. Robben. Cambridge: Cambridge University Press, 70-101.

Rudebeck, E., 2002. Vägen som rituell arena, in Plats och praxis: studier av nordisk förkristen ritual, eds. K. Jennbert, A. Andrén \& C. Raudvere. (Vägar till Midgård 2.) Lund: Nordic Academic Press, 167-200.

Schmidt, B.E. \& I.W. Schröder (eds)., 2001. Anthropology of Violence and Conflict. London: Routledge.

Sjøvold, T., 1994. Importance and certain features of the skeletal remains, in Prehistoric Graves as a Source of Information, ed. B. Stjernquist. Symposium as Kastrlösa, Öland, May 21-23, 1992. (Konferenser 29.) Stockholm: Kungl. Vitterhets Historie och Antikvitets Akademien, 211-23.

Skarin-Frykman, B., 1967. Eketorps borg. A study of the origin of some Öland forts. Tor 11, 198-229.

Sluka, J.A., 1992. The anthropology of conflict, in The Paths to Domination, Resistance, and Terror, eds. C. Nordstrom \& J. Martin. Berkeley (CA): University of California Press, 18-36.

Stenberger, M., 1933. Öland under äldre järnåldern. En bebyggelsehistorisk undersökning. Stockholm: Kungliga Vitterhetsakademien. 
Suárez-Orozco, M.M. \& A.C.G.M. Robben, 2000. Interdisciplinary perspectives on violence and trauma, in Cultures under Siege: Collective violence and trauma, eds. A.C.G.M. Robben \& M.M. Suárez-Orozco. Cambridge: Cambridge University Press, 194-226.

Sundquist, O., 2002. Freyr's offspring. Rulers and religion in ancient Svea society. (Historia Religionum 21.) Uppsala: Uppsala University.

Tarlow, S., 1999. Bereavement and Commemoration: An archaeology of mortality. Oxford: Blackwell.

Tarlow, S., 2000. Emotion in archaeology. Current Anthropology 41(5), 713-46.

Thäte, E.S., 2007. Monuments and Minds. Monument re-use in Scandinavia in the second half of the first millennium $A D$. (Acta Archaeologica Lundensia series in $4^{\circ}$ 27.) Lund: Lund University.

Thomas, L-V., 1975. Anthropologie de la mort. Paris: Payot.

Tung, T.A., 2014. Agency, 'til death do us part? Inquiring about the agency of dead bodies from the ancient Andes. Cambridge Archaeological Journal 24(3), 437-52.

Tylor, E.B., 1903. Primitive Culture: Researches into the development of mythology, philosophy, religion, language, art, and custom, vol. 2. London: John Murray.

Van Gennep, A., 1960. The Rites of Passage. London: Routledge \& Kegan Paul.

Verdery, K., 1999. The Political Lives of Dead Bodies: Reburial and postsocialist change. New York (NY): Columbia University Press.

Viberg, A., 2012. Remnant Echoes of the Past: Archaeological geophysical prospection in Sweden. (Theses and Papers in Scientific Archaeology 13). Stockholm: Stockholm University.

Victor, H., 2012. Sandby borg II. Undersökningar 2012. Sandby socken, Mörbylånga kommun, Öland. Kalmar: Kalmar läns museum.

Victor, H., 2014. Sandby borg IV. Undersökningar 2014. Sandby socken, Mörbylånga kommun, Öland. Kalmar: Kalmar läns museum.

Victor, H., 2015. Sandby borg. Ett fruset ögonblick under folkvandringstiden, in Grävda minnen. Från Skedemosse till Sandby borg, eds. K.-H. Arnell \& L. Papmehl-Dufay. (Meddelanden från Kalmar läns hembygdsförbund och Stiftelsen Kalmar läns museum 95.) Kalmar: Kalmar läns museum, 96-115.
Victor, H., A. Emilsson \& M. Frisk, 2013. Sandby borg III. Undersökningar 2013. Sandby socken, Mörbylånga kommun, Öland. Kalmar: Kalmar läns museum.

Wagner, S.E., 2008. To Know Where He Lies: DNA technology and the search for Srebrenica's missing. Berkeley (CA): University of California Press.

Wegraeus, E., 1976. The Öland ring-forts, in Eketorp: Fortification and settlement on Öland/Sweden: The monument, eds. K. Borg, U. Näsman \& E. Wegraeus. Stockholm: Almqvist \& Wiksell, 33-44.

Weiss-Krejci, E., 2008. Unusual life, unusual death and the fate of the corpse: a case study from dynastic Europe, in Deviant Burial in the Archaeological Record, ed. E. M. Murphy. Oxford: Oxbow, 169-90.

Weiss-Krejci, E., 2011. The formation of mortuary deposits: implications for understanding mortuary behavior of past populations, in Social Bioarchaeology, eds. S. C. Agarwal \& B.A. Glenncross. New York (NY): Wiley-Blackwell, 68-106.

Weiss-Krejci, E., 2013. The unburied dead, in The Oxford Handbook of the Archaeology of Death and Burial, eds. L. Nilsson Stutz \& S. Tarlow. Oxford: Oxford University Press, 281-301.

Whitehead, N.L., 2004. On the poetics of violence, in Violence, ed. N.L. Whitehead. Santa Fe (NM): School of American Research Press, 55-77.

Whitehead, N.L., 2005. War and violence as cultural expression. Anthropology News 46, 23-6.

Wilhelmson, H., 2017. Perspectives from a Human-centered Archaeology: Iron Age people and society on Öland. Lund: Lund University.

Zachrisson, T., 1994. The odal and its manifestation in the landscape. Current Swedish Archaeology 2, 219-38.

\section{Author biography}

Clara Alfsdotter is currently a $\mathrm{PhD}$ candidate at Linnaeus University. She has a background in osteology and prehistoric archaeology. She has mainly been working within development-led archaeology in Sweden and Denmark. Her current bioarchaeological research focuses on the treatment of the dead, both theoretically and taphonomically. Current research includes Iron Age mortuary practice and osteological and forensic taphonomy, with emphasis on archaeothanatology and experimental studies. 